\title{
Quantitative cell-adhesion assay for Clostridium difficile cytotoxin
}

\author{
B. C. MAYALL, CAROLINE EDMONDS* and G. E. GRIFFIN†
}

Departments of Communicable Diseases and "Immunology, St George's Hospital Medical School, Tooting, London SW17 ORE

\begin{abstract}
Summary. A quantitative assay for Clostridium difficile cytotoxin has been developed, based on the observation that suspended fibroblasts exposed to cytotoxin fail to adhere to plastic. A dye-binding technique was used to quantitate adherent cells, in order to obviate microscopy. Adherent BHK cells were fixed with glutaraldehyde and cell protein was stained with Coomassie blue R-250. Cell-bound dye was eluted and estimated spectrophotometrically. The amount of eluted dye was proportional to the number of adherent cells and cell staining was time dependent. Cytotoxin was purified by gel-permeation and ion-exchange chromatography and migrated as a single band on SDS-PAGE. After exposure of suspended BHK cells to purified cytotoxin, their adhesion to plastic was inhibited in a manner which depended on concentration of cytotoxin and on time and temperature of exposure. This study provides the basis for a $C$. difficile cytotoxin assay that is quantitative, rapid and reproducible and may have wider applicability in the study of other toxins or agents that inhibit cell adhesion.
\end{abstract}

\section{Introduction}

Clostridium difficile is responsible for antibioticassociated colitis in man (Bartlett et al., 1978; George et al., 1978), and for caecitis in the antibiotic-treated hamster (Bartlett et al., 1977). Two toxins mediating mucosal damage are produced by the organism, enterotoxin (toxin A) and cytotoxin (toxin B) (Taylor et al., 1981). The relative contribution of each toxin to colitis in man is unknown but in the hamster model, caecitis appears to be dependent on the simultaneous activity of both toxins (Libby et al., 1982).

Cytotoxin causes characteristic rounding up of many tissue-culture cell lines (Thelestam and Bronnegard, 1980), and this phenomenon is widely used in its detection. There appears to be little correlation between titre of cytotoxin in stool and clinical severity of disease (George et al., 1982), so accurate quantitation of cytotoxin in clinical laboratories has been thought to be unhelpful, either diagnostically or prognostically. However, in a number of areas it is important to be able to quantitate cytotoxin, e.g., to investigate the stability and biological degradation of cytotoxin in different conditions. Immunoassays have been described (Yolken et al., 1981 ; Aronsson et al., 1983; Peterson et al., 1986), but do not detect biological activity.

Received 19 May 1986; revised version accepted 7 Nov. 1986. † Correspondence should be sent to Dr G. E. Griffin.
Conventional assays based on cell rounding are subject to errors of the order of \pm 10 -fold (Pothoulakis et al., 1986). C. difficile cytotoxin is conventionally detected by its cytopathic effect on fibroblasts. This test relies upon microscopy of cells and at limits of dilution is inherently subjective and imprecise. Therefore, we developed a quantitative bio-assay based on our observation that $C$. difficile cytotoxin inhibits adhesion of BHK cells to plastic tissue-culture plates.

\section{Materials and methods}

\section{Cells}

BHK cells (Flow Laboratories) were grown to at least $90 \%$ confluence in growth medium (GM) consisting of Ham's F10 medium (Flow Laboratories) supplemented with newborn calf serum (Gibco) $5 \% \mathrm{v} / \mathrm{v}, 2 \mathrm{mM}$ glutamine, penicillin $50 \mathrm{U} / \mathrm{ml}$ and streptomycin $50 \mu \mathrm{g} / \mathrm{ml}$. Cells were incubated at $37^{\circ} \mathrm{C}$ in a humid atmosphere containing $\mathrm{CO}_{2}, 5 \% \mathrm{v} / \mathrm{v}$. All cell manipulations were performed in GM.

\section{Cell adhesion}

BHK cells were trypsinised with fresh trypsin EDTA solution (Flow Laboratories) at $37^{\circ} \mathrm{C}$ for $1 \mathrm{~min}$ and were then suspended in GM in polycarbonate screw-top vials. For adhesion assays, $0 \cdot 5-\mathrm{ml}$ volumes were transferred to Multi-well (Sterilin, Feltham) tissue-culture plates con- 
sisting of $254-\mathrm{cm}^{2}$ wells, dispersed evenly by transient gentle rocking, and incubated at $37^{\circ} \mathrm{C}$ in $\mathrm{CO}_{2} 5 \% \mathrm{v} / \mathrm{v}$ for $2 \mathrm{~h}$ to allow adhesion. During incubation, direct contact between Multi-well plates and metal incubator trays was prevented by interposition of a plastic flask, to avoid temperature-dependent differences in cell adhesion (Adler et al., 1982). After incubation, plates were washed three times with phosphate-buffered saline (PBS) $p \mathrm{H} \mathrm{7.2}$ containing (/L) $\mathrm{NaCl} 8 \mathrm{~g}, \mathrm{KCl} 0.2 \mathrm{~g}, \mathrm{Na}_{2} \mathrm{HPO}_{4} .12 \mathrm{H}_{2} \mathrm{O}$ $1.15 \mathrm{~g}, \mathrm{KH}_{2} \mathrm{PO}_{4} 0.2 \mathrm{~g}$, and adherent cells were quantitated as described below.

\section{Quantitation of cell protein of adherent BHK cells (dye-binding assay)}

BHK cells adhering to plates after washing were fixed with glutaraldehyde (BDH) $3 \% \mathrm{w} / \mathrm{v}$ in PBS for $20 \mathrm{~min}$ at room temperature. A stock solution of Coomassie brilliant blue R-250 (C.1. 42660) (PAGE blue 83; BDH) $0.4 \mathrm{~g}$ in $880 \mathrm{ml}$ of ethanol $30 \% \mathrm{v} / \mathrm{v}$ was mixed with glacial acetic acid immediately before use to make a final acid solution of $12 \% \mathrm{v} / \mathrm{v}$. The solution was then filtered (Whatman's No. 1 filter paper). The cells were stained with Coomassie blue solution for $30 \mathrm{~min}$ at room temperature, then washed three times with an aqueous solution containing acetic acid $5 \% \mathrm{v} / \mathrm{v}$ and ethanol $10 \% \mathrm{v} / \mathrm{v}$ to remove unbound dye. Protein-bound dye was eluted at room temperature with $1.0 \mathrm{M}$ potassium acetate (general purpose grade) in ethanol $70 \% \mathrm{v} / \mathrm{v}$ for $15 \mathrm{~min}$. After gentle rocking to ensure homogeneity, the absorbance of the eluate was measured spectrophotometrically at $590 \mathrm{~nm}$. Prolonged elution times were unreliable because of evaporation of ethanol. Background dye-binding by the newborn calf serum from GM was estimated in each plate by incubating GM alone in triplicate; the mean value was subtracted from the absorbance found with adherent cells.

\section{Cytotoxin preparation}

A single strain of $C$. difficile was isolated from a patient with pseudomembranous colitis and identified as described by Borriello and Honour (1981). The original isolate was maintained in cooked-meat medium. For cytotoxin preparation, a subculture from Cysteine Blood Agar (Oxoid) was cultured in Brain Heart Infusion Broth (Oxoid) in an anaerobic cabinet $\left(\mathrm{N}_{2} 85 \%, \mathrm{H}_{2}, 5 \%, \mathrm{CO}_{2}\right.$ $10 \%$ ) for 5 days at $37^{\circ} \mathrm{C}$. All steps in the preparation of cytotoxin were performed at $4^{\circ} \mathrm{C}$. Culture broth was centrifuged $(10000 \mathrm{~g}$ for $30 \mathrm{~min})$, membrane filtered $(0.45 \mu \mathrm{m}$; Millipore), and concentrated by ammonium sulphate precipitation by the procedure described by Pothoulakis et al. (1986), except that PBS was used instead of Tris- $\mathrm{HCl}$ solution. The precipitate obtained from the ammonium sulphate solution was dissolved in PBS and dialysed overnight against 100 volumes of PBS. This solution was fractionated by Sephacryl S-300 gelpermeation chromatography with PBS as the eluant.
Volumes of $0.025 \mathrm{ml}$ of each column fraction were added to 96-well plates (Costar, Cambridge, MA, USA) with each well containing confluent BHK cells in $0.2 \mathrm{ml}$ of GM. Fractions causing characteristic cell rounding at $30 \mathrm{~min}$ were pooled and, after overnight dialysis against $0.05 \mathrm{M}$ Tris- $\mathrm{HCl} p \mathrm{H} \mathrm{7.5}$, were further purified by ionexchange chromatography through a DEAE-Sepharose CL-6B column $(1.5 \mathrm{~cm} \times 10 \mathrm{~cm})$, eluting sequentially with 60 -ml volumes of $0.05 \mathrm{M}$ Tris buffer, $p \mathrm{H} 7.5$, containing $0 \cdot 05,0 \cdot 2,0 \cdot 25,0 \cdot 3,0 \cdot 32,0 \cdot 34$ and $0.4 \mathrm{M} \mathrm{NaCl}$ respectively. The flow rate was $60 \mathrm{ml} / \mathrm{h}$ with fraction volumes of $5 \mathrm{ml}$. Fractions causing cell rounding at $30 \mathrm{~min}$ were filtered $\left(0.45 \mu \mathrm{m}\right.$; Millipore) and stored at $4^{\circ} \mathrm{C}$. Control experiments showed that cytotoxicity was not influenced by the different $\mathrm{NaCl}$ concentrations. Filtered cytotoxin fractions were dialysed overnight against Ham's F10 medium and stored at $4^{\circ} \mathrm{C}$ before use within $48 \mathrm{~h}$ in the experiments described below.

Cytotoxic fractions purified by ion-exchange chromatography were concentrated with Aquacide Type I, mol. wt 70000 (Calbiochem) and subjected to polyacrylamide gel electrophoresis with $0.2 \mathrm{M}$ glycine, $0.025 \mathrm{M}$ Tris running buffer, $p \mathrm{H} 8.3$ in dissociating (SDS) and nondissociating conditions (Laemmli, 1970). Solubilising buffer consisted of $\beta$-mercaptoethanol $0.5 \% \mathrm{v} / \mathrm{v}$, SDS $1 \% \mathrm{w} / \mathrm{v}$, glycerol $0.5 \% \mathrm{v} / \mathrm{v}, 0.1 \mathrm{M}$ Tris $p \mathrm{H} 6.8$. The sample buffer for non-dissociating conditions was $1.0 \mathrm{M}$ Tris$\mathrm{HCl} p \mathrm{H} 6.7$, glycerol $10 \% \mathrm{v} / \mathrm{v}$ and bromophenol blue $0.1 \% \mathrm{v} / \mathrm{v}$. In non-dissociating and dissociating conditions, a single protein band was seen after Coomassie blue staining. Extrapolating from concurrent mol.-wt standards, this protein had a mol. wt of $54( \pm 2) \times 10^{3}$.

\section{Inhibition of cell adhesion by cytotoxin}

Purified cytotoxin was added in the ratio of $1: 20(\mathrm{v}: \mathrm{v})$ to cells incubated in suspension by rolling (Spiramix; Denley Instruments). After $30 \mathrm{~min}, 0 \cdot 5-\mathrm{ml}$ samples were added to Multi-well plates for adhesion assay. In some experiments, $C$. sordelli antiserum (Wellcome) sufficient to neutralise all cytotoxin present (Chang et al., 1978) was added before plating. Cells exposed to cytotoxin were allowed to adhere to Multi-well plates for $2 \mathrm{~h}$. Adhesion of cells exposed to cytotoxin was compared to that of non-exposed control cells and the ratio (cytotoxin exposed: non-exposed) expressed as a percentage.

For the preparation of highly purified cytotoxin from the DEAE Sepharose columns, $400 \mathrm{ml}$ of broth filtrate was used as the starting material. Even after concentration of fractions from the ion exchange column the amount of protein in solution was below the lower limit of detection of micro-Lowry and Coomassie blue spectrophoto assays. Thus the actual mass of cytotoxin used in the cell binding assays was unknown. A dilution of the cytotoxin preparation causing c. $90 \%$ inhibition of adherence was used as the most concentrated sample (figs 2 and 3). At this concentration of cytotoxin, cell rounding was not detectable after incubation for $2 \mathrm{~h}$, as used in adherence assays, but was apparent after incubation for $36 \mathrm{~h}$. 


\section{Results}

\section{Validation of technique to quantitate adherent cells}

Time dependence of cell adhesion. BHK cells incubated in suspension in polycarbonate screwtop vials with rolling for $30 \mathrm{~min}$ were plated out and allowed to adhere for $1.5,2,2.5$ and $3 \mathrm{~h}$, after which adherent cell protein was estimated by the dye-binding technique. Cell adhesion was maximal at $2 \mathrm{~h}$ after plating and remained constant thereafter.

Relationship of cell number to dye binding. Cells previously incubated in suspension with rolling for 30 min were counted with a Coulter counter, diluted and allowed to adhere in Multi-well chambers for $2 \mathrm{~h}$. Adherent cell protein was estimated spectrophotometrically, as described. Cell number was plotted against absorbance of eluted Coomassie blue dye (fig. 1). For cell numbers of $(0 \cdot 5-3) \times$ $10^{5} / \mathrm{ml}$, there was an approximately linear relationship between number and absorbance. With cell numbers above $3 \times 10^{5} / \mathrm{ml}$, the absorbance values began to plateau. In further experiments, cell suspensions containing about $1.5 \times 10^{5}$ cells $/ \mathrm{ml}$ were used. This concentration was obtained by trypsinising cells grown to confluence in a $75-\mathrm{cm}^{2}$ flask and suspending these in $30 \mathrm{ml}$ of GM.

Plate to plate variation. A suspension of $\mathrm{BHK}$ cells was rolled for $30 \mathrm{~min}$ and samples were allowed to adhere for $2 \mathrm{~h}$ in triplicate wells in each

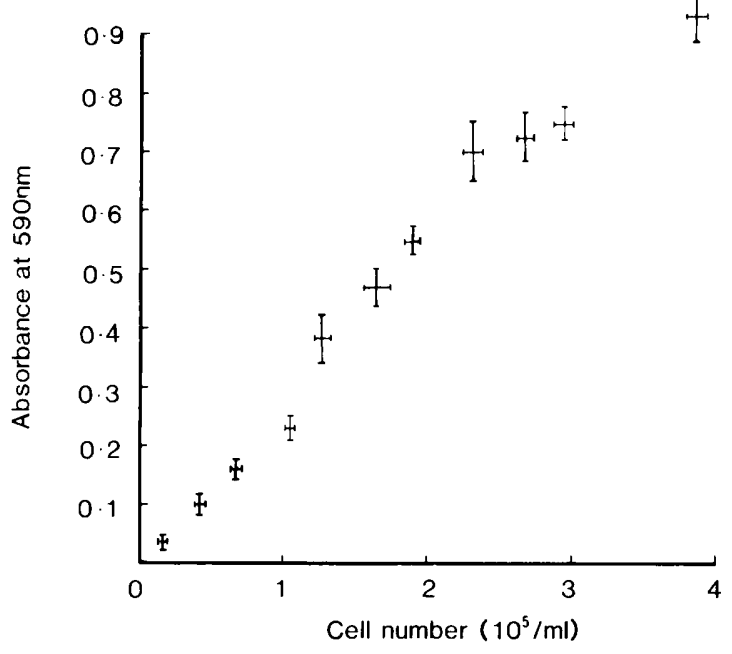

Fig. 1. Coomassie blue staining of adherent BHK cells. Cells were allowed to adhere to Multi-well plates for $2 \mathrm{~h}$ and were washed, fixed and stained for $30 \mathrm{~min}$ with Coomassie blue. Stain was eluted and measured spectrophotometrically. The numbers of cells (mean $\pm S E M$ ) initially in suspension are plotted against absorbance (mean \pm SEM) of four different Multi-well plates. Adherent cell protein was estimated by the dye-binding technique and mean absorbance values (SEM) for each plate were; $0.597(0.011), 0.615(0.028), 0.560(0.019)$ and $0.587(0.024)$. Plate-to-plate variation in absorbance was comparable to intra-plate variation. Analysis of variance showed that inter-plate variation was not significant $(p=0 \cdot 16)$. Thus, different plates could be compared directly.

Intra-plate variation. Two concentrations of cytotoxin, known to inhibit cell adhesion by around $30 \%$ and $50 \%$ respectively, were selected. Each sample of cytotoxin was assayed in decuplicate on one Multi-well plate. One concentration resulted in adherence of $34 \cdot 1$ (SD 3.7) $\%$ and the other $48 \cdot 2$ (SD $5 \cdot 7) \%$.

Effect of rolling cells on cell staining. Suspended BHK cells, rolled for $0,1.5,2.5$ and $3.5 \mathrm{~h}$ at $37^{\circ} \mathrm{C}$, were plated out in triplicate and allowed to adhere for $2 \mathrm{~h}$. There was little difference in cell staining after rolling for up to $1.5 \mathrm{~h}$, but after rolling for $3.5 \mathrm{~h}$ staining was reduced by $15 \%$. Therefore, a rolling time of $30 \mathrm{~min}$ did not affect cell staining, and this time was used in quantitation experiments.

Time dependence of cell staining. Cells rolled for $30 \mathrm{~min}$ were plated out and allowed to adhere for $2 \mathrm{~h}$. After fixation, cells were stained for $30 \mathrm{~min}$ or $120 \mathrm{~min}$. Protein-bound dye increased by $43 \%$ between $30 \mathrm{~min}$ and $120 \mathrm{~min}$ of staining. We noted that prolonged staining $(16 \mathrm{~h})$ resulted in much higher dye-binding, but this was not quantitated. Thus a fixed time of $30 \mathrm{~min}$ staining was used in all quantitation experiments.

\section{Inhibition of $B H K$ cell adhesion by $C$. difficile cytotoxin}

Time dependence. Cytotoxin was added to cells and $C$. sordelli antiserum added to samples taken after rolling for $5,10,15,20,30,40,50$ and $60 \mathrm{~min}$. A zero-time sample was prepared by incubating cytotoxin with antiserum for $5 \mathrm{~min}$ at room temperature before addition of cells (fig. 2). No inhibition of adherence was detected in cells exposed to the cytotoxin-antiserum mixture compared with adherence of non-exposed cells. Inhibition of cell adhesion was observed after exposure to cytotoxin for 5 min and increased with time.

Concentration dependence. Serial $1 \cdot 5$-fold dilutions of cytotoxin were incubated with suspended cells for $30 \mathrm{~min}$ at $37^{\circ} \mathrm{C}$ and antiserum added (fig. 3). There was an approximately linear relationship between cytotoxin concentration and inhibition of 


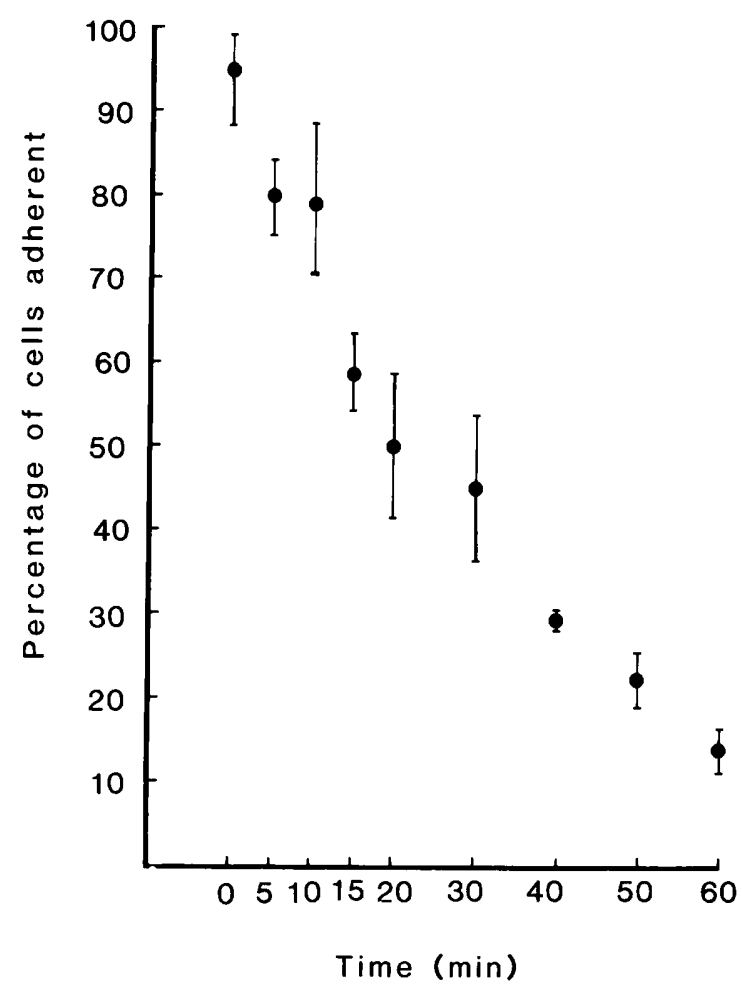

Fig. 2. Time course of inhibition of BHK cell adherence by $C$. difficile cytotoxin. BHK cells in suspension were exposed to a fixed concentration of purified $C$. difficile cytotoxin at $37^{\circ} \mathrm{C}$. At the time shown, $C$, sordelli antiserum was added to cells which were allowed to adhere to Multi-well plates for $2 \mathrm{~h}$ in the presence of antiserum. Adherent cells were assayed by the Coomassie blue dye-binding technique. Results are expressed as mean percentage adherence compared to cells not exposed to cytotoxin (bar = SEM).

cell adherence in a given range. A two-fold increase in cytotoxin concentration resulted in a reduction of c. $20 \%$ in cell adherence, and a change from $20 \%$ to $80 \%$ cell adhesion represented a 5- to 6 -fold concentration range. Below $20 \%$ and above $80 \%$ inhibition, results were non-linear. The same relationship was observed with a series of dilutions of crude $C$. difficile broth-culture filtrate containing cytotoxin.

Temperature dependence. Samples from a cell suspension were incubated at $4^{\circ}, 20^{\circ}$, and $37^{\circ} \mathrm{C}$ in triplicate. Each sample was exposed to the same concentration of cytotoxin and $C$. sordelli antiserum was added $30 \mathrm{~min}$ after addition of cytotoxin. Cells were allowed to adhere to Multi-well plates at $37^{\circ} \mathrm{C}$ for $2 \mathrm{~h}$. Cytotoxin reduced cell adherence by $60 \%$ at $37^{\circ} \mathrm{C}, 22 \%$ at $20^{\circ} \mathrm{C}$, and $13 \%$ at $4^{\circ} \mathrm{C}$. (These results are expressed as the percentage adherence when compared to control cells rolled for $30 \mathrm{~min}$ at

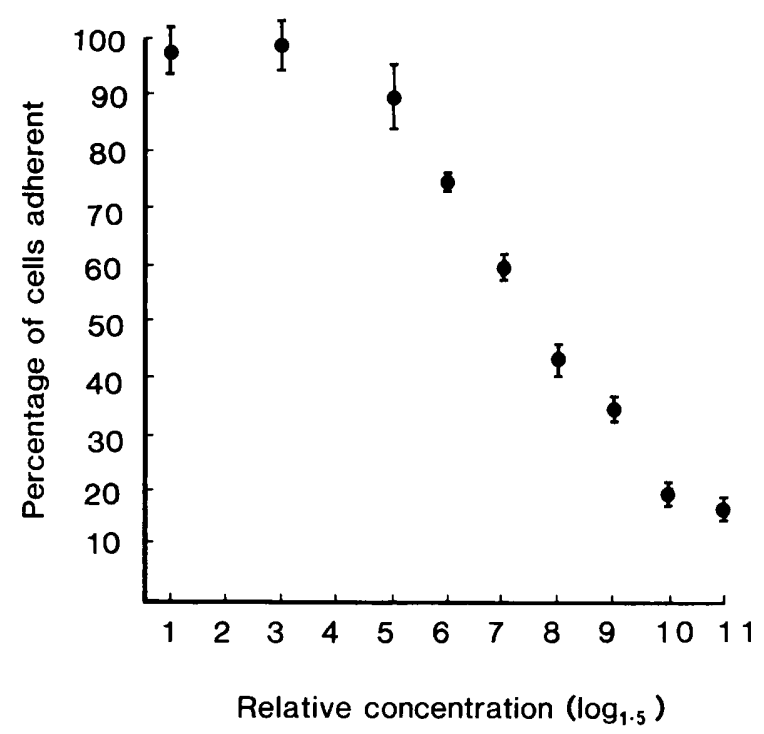

Fig. 3. Concentration dependence of inhibition of BHK cell adherence by $C$. difficile cytotoxin. BHK cells in suspension were exposed to a range of concentrations of purified $C$. difficile cytotoxin for $30 \mathrm{~min}$ at $37^{\circ} \mathrm{C}$. Cells were allowed to adhere to Multi-well plates for $2 \mathrm{~h}$ at $37^{\circ} \mathrm{C}$. Adherent cells were washed, fixed and assayed by the Coomassie blue dye-binding technique. Results (mean \pm SEM) are expressed as percentage adherence compared to cells not exposed to cytotoxin.

the same temperature but not exposed to cytotoxin.) Thus, exposure of BHK cells to cytotoxin at different temperatures markedly affected the degree of subsequent inhibition of cell adherence.

\section{Discussion}

Previous assays of $C$. difficile cytotoxin have relied on observation of morphological changes in cells in tissue culture. These assays are subjective and prone to observer error and are thus inaccurate and poorly standardised. We set out to develop a sensitive quantitative bioassay for $C$. difficile cytotoxin, using our observation that cytotoxin inhibited adhesion of BHK cells to plastic tissue-culture plates. To quantitate adherent cells without direct cell counting, we assayed cell protein by a Coomassie blue dye-binding technique.

We have demonstrated that adherent BHK cell. numbers can be estimated indirectly by measuring eluted Coomassie blue dye. A linear relationship was found between absorbance of eluted dye and cell concentration in the original suspension in the range $(0 \cdot 5-3) \times 10^{5} / \mathrm{ml}$. Although we did not count adherent cells directly, it has previously been reported that about $80 \%$ of suspended BHK cells adhered to plastic tissue-culture plates in conditions 
similar to our own (Nath and Srere, 1977). Furthermore, we showed that in control conditions, in the absence of cytotoxin, BHK cell adhesion to plastic tissue-culture plates was maximal in $2 \mathrm{~h}$. This was somewhat slower than previously observed by Nath and Srere (1977), but this may have been due to differences in several factors, including composition of serum (Knox, 1984), substrate surface (Curtis et al., 1983), and the amount of shear applied when washing unbound cells from plates.

Staining of BHK cells with Coomassie blue R250 is time dependent. This parallels the findings of Barer et al. (1986) and Laughton (1984) who pointed out that in each cell system, staining kinetics should be estimated. In the system employed in this study with BHK cells, exposure to Coomassie blue for $30 \mathrm{~min}$ gave a suitable range of absorbance values.

Adherent cells have been quantitated by several methods including direct microscopy (Patterson, 1979), assay of cell enzymes (Connolly et al., 1986) or estimation of cell protein (Laughton, 1984; Shopsis and Mackay, 1984; Baumgarten, 1985). One method (Shopsis and Mackay, 1984) required initial lysis of cells before Lowry micro-assay of cell protein. Other Coomassie blue protein dye-binding assays have been described (Laughton, 1984; Baumgarten, 1985). These used a modification of the Bradford protein assay (Bradford, 1976), which depends on the colour change of Coomassie blue $\mathrm{G}-250$ at low $p \mathrm{H}$ from brown-red to blue when bound to protein. The assay described in the current study relies on the fact that binding of Coomassie blue R-250 to protein is reversible in suitable conditions (Fazekas de St Groth et al., 1963), and thus bound dye may be eluted from cells.

The purified $C$. difficile cytotoxin ran as a single band on SDS-PAGE gel. The estimated mol. wt of $54 \times 10^{3}$ was similar to that found by Pothoulakis et al. (1986). Using the Coomassie blue dye-binding method validated above, we examined the inhibition of BHK cell adhesion caused by this preparation. The time of cytotoxin exposure of suspended BHK cells was varied by adding $C$. sordelli antiserum to samples of a cell suspension at defined times to prevent further toxin activity. Cells were then allowed to adhere in the continued presence of antiserum. The first measurement of cell adherence after 5 min was less than the control value (obtained when cytotoxin was neutralised by antiserum for $5 \mathrm{~min}$ before addition of cells) and inhibition of cell adhesion increased with further exposure. Thus, cytotoxin decreased the ability of BHK cells to adhere after short exposures to cytotoxin. Increasing concentrations of cytotoxin increased the rate of inhibition of cell adhesion (results not shown).

When cells were exposed for a fixed time ( $30 \mathrm{~min})$ to a range of cytotoxin concentrations, inhibition of cell adhesion was proportional to the logarithm of the concentration. This relationship was found to be constant both for a crude broth-culture filtrate and for highly purified toxin. A six-fold increase in cytotoxin concentration decreased cell adhesion from $80 \%$ to $20 \%$, and within this six-fold range cytotoxin concentrations could be quantitated.

Temperature of exposure markedly affected interaction between cells and cytotoxin; therefore, assays must be performed at controlled temperature. Temperature dependence of interaction of $C$. difficile cytotoxin and adherent cell morphology was demonstrated by Florin and Thelestam (1981). The molecular events following exposure of cells to C. difficile cytotoxin are still unknown, but temperature-dependent internalisation of other toxin molecules has been described (Montesano et al., 1982).

Other biological effects of $C$. difficile cytotoxin on cultured fibroblasts have been demonstrated. Thelestam and Bronnegard (1980) used a fluorescent antibody to label actin, and described disruption of straight actin bundles in human lung fibroblasts exposed to semi-purified cytotoxin. Wedel et al. (1983), using electronmicroscopy, demonstrated that partially-purified cytotoxin caused disruption of actin-containing myofilaments in smooth muscle cells from rabbit aorta. Pothoulakis et al. (1986), using a highly purified cytotoxin preparation, showed that cell rounding of IMR-90 fibroblasts was related to the ratio of globular to filamentous actin. The change in actin configuration, first demonstrated at $15 \mathrm{~min}$, was nearly complete at the onset of detectable cell rounding 30-60 min). This is thought to be an important intracellular event preceding morphological change. Using the Coomassie blue dye-binding technique, we demonstrated that brief exposure ( $5 \mathrm{~min}$ ) of BHK cells to purified cytotoxin caused inhibition of cell adhesion.

Other actions of the cytotoxin that have unknown pathophysiological significance include inhibition of protein and nucleic acid synthesis (Florin and Thelestam, 1981) and electrolyte leakage from affected cells (Rothman et al., 1984). The stimulation of guanylate cyclase and inhibition of adenylate cyclase were reported by Vesely et al. (1981), but have yet to be confirmed. Biochemical studies on the biological target of the toxins of $C$. difficile, namely, the colonocyte, are still to be performed. 
Other toxins inhibit the adhesion of fibroblasts to plastic wells. For example, the enterotoxin of $C$. perfringens has been shown to be active in this respect. McClane and McDonel (1979) demonstrated inhibition of cell adhesion after exposure of Vero cells to $C$. perfringens enterotoxin by use of direct microscopy to quantitate cells. We confirmed that $C$. perfringens enterotoxin inhibited cell adhesion by the dye-binding technique; we found that concentrations of the order of $1-100 \mu \mathrm{g} / \mathrm{ml}$ were necessary to obtain measurable inhibition of BHK cell adhesion after exposure for $30 \mathrm{~min}$. Some toxins however, may have no effect on cell adhesion and therefore this assay would not be applicable to these toxins. For example, exposure of BHK cells to cholera toxin, even at high concentration (10 nM), did not inhibit adhesion (unpublished observation).

BCM was supported by a Royal Australian College of Physicians Merck, Sharp and Dohme (Australia) Travelling Fellowship in Infectious Diseases. CE was supported by a MRC Research Studentship. GEG was supported by the Wellcome Trust. The authors acknowledge the expert technical assistance of A. McDougall and helpful discussion with Dr P. Knox. Dr S. P. Borriello isolated and kindly provided the $C$. difficile strain used.

\section{REFERENCES}

Adler E M, Fluk L J, Mullin J M, Kleinzeller A 1982 Anomalous patterns in cultured cell monolayers. Science 217: 851-853.

Aronsson B, Granström M, Möllby R, Nord C E 1983 Enzymelinked immunosorbent assay (ELISA) for antibodies to Clostridium difficile toxins in patients with pseudo-membranous colitis and antibiotic-associated diarrhoea. Journal of Immunological Methods 60: 341-350.

Barer M, Lyon H O, Drasar B S 1986 Quantitation of dyebinding to cell monolayers in a microtitre system. Histochemistry, 18: 122-128.

Bartlett J G, Onderdonk A B, Cisneros R L, Kasper D L 1977 Clindamycin-associated colitis due to a toxin-producing species of Clostridium in hamsters. Journal of Infectious Diseases 136: 701-705.

Bartlett J G, Chang T W, Gurwith M, Gorbach S L, Onderdonk A B 1978 Antibiotic-associated pseudomembranous colitis due to toxin-producing clostridia. New England Journal of Medicine 298: 531-534.

Baumgarten H 1985 A simple microplate assay for the determination of cellular protein. Journal of Immunological Methods 82: 25-37.

Borriello S P, Honour P 1981 Simplified procedure for the routine isolation of Clostridium difficile from faeces. Journal of Clinical Pathology 34: 1124-1126.

Bradford M M 1976 A rapid and sensitive method for the quantitation of microgram quantities of protein utilizing the principle of protein dye-binding. Analytical Biochemistry 72: 248-254.

Chang T-W, Gorbach S L, Bartlett J B 1978 Neutralization of Clostridium difficile toxin by Clostridium sordellii antitoxins. Infection and Immunity 22: 418-422.

Connolly D T, Knight M B, Harakas N K, Wittwer A J, Feder J 1986 Determination of the number of endothelial cells in culture using an acid phosphatase assay. Analytical Biochemistry 152 : $136-140$.

Curtis A S G, Forrester J V, McInnes C, Lawrie F 1983 Adhesion of cells to polystyrene surfaces. Journal of Cell Biology 97: 1500-1506.

Fazekas de St Groth S, Webster R G, Datyner A 1963 Two new staining procedures for quantitative estimation of proteins on electrophoretic strips. Biochimica et Biophysica Acta 71 : 377-391.

Florin I, Thelestam M 1981 Intoxication of cultured human lung fibroblasts with Clostridium difficile toxin. Infection and Immunity 33: 67-74.

George R H et al. 1978 Identification of Clostridium difficile as a cause of pseudomembranous colitis. British Medical Journal 1: 695

George W L, Rolfe R D, Finegold S M 1982 Clostridium difficile and its cytotoxin in feces of patients with antimicrobial agent-associated diarrohea and miscellaneous conditions. Journal of Clinical Microbiology 15: 1049-1053.

Knox P 1984 Kinetics of cell spreading in the presence of different concentrations of serum or fibronectin-depleted serum. Journal of Cell Science 71 : 51-59.

Laemmli U K 1970 Cleavage of structural proteins during the assembly of the head of bacteriophage T 4 . Nature 227: 680 685.

Laughton C 1984 Quantification of attached cells in microtiter plates based on Coomassie Brilliant blue G-250 staining of total cellular protein. Analytical Biochemistry 140: 417-423.

Libby J M, Jortner B S, Wilkins T D 1982 Effects of the two toxins of Clostridium difficile in antibiotic-associated cecitis in hamsters. Infection and Immunity 36: 822-829.

McClane B A, McDonel J L 1979 The effects of Clostridium perfringens enterotoxin on morphology, viability, and macromolecular synthesis in Vero cells. Journal of Cellular Physiology 99: 191-200.

Montusano R, Roth J, Robert A, Orci L 1982 Non-coated membrane invaginations are involved in binding and internalization of cholera and tetanus toxins. Nature 296: 651-653.

Nath K, Srere P A 1977 Effects of temperature, metabolic and cystoskeletal inhibitors on the rate of BHK cell adhesion to polystyrene. Journal of Cellular Physiology 92 : 33-42.

Patterson M K 1979 Measurement of growth and viability of cells in culture. Methods in Enzymology 58: 141-152.

Peterson L R, Holter J J, Shanholtzer C J, Garrett C R, Gerding D N 1986 Detection of Clostridium difficile toxins A (enterotoxin) and B (cytotoxin) in clinical specimens. Evaluation of a latex agglutination test. American Journal of Clinical Pathology 86: 208-211.

Pothoulakis C et al. 1986 Purification and properties of Clostridium difficile cytotoxin B. Journal of Biological Chemistry 261 : 1316-1321.

Rothman S W, Brown J E, Diecidue A, Foret D A 1984 Differential cytotoxic effects of toxins A and B isolated from Clostridium difficile. Infection and Immunity 46; 324 331.

Shopsis C, Mackay G J 1984 A semi-automated protein assay for cell cultures. Analytical Biochemistry 140: 104-107.

Taylor N S, Thorne G M, Bartlett J G 1981 Comparison of two 
toxins produced by Clostridium difficile. Infection and Immunity 34: 1036-1043.

Thelestam M, Bronnegard M 1980 Interaction of cytopathogenic toxin from Clostridium difficile with cells in tissue culture. Scandinavian Journal of Infectious Diseases, Suppl 22: 1629.

Vesely D L, Straub K D, Nolan C M, Rolfe R D, Finegold S M, Monson T P 1981 Purified Clostridium difficile cytotoxin stimulates guanylate cyclase activity and inhibits adenylate cyclase activity. Infection and Immunity 33 : 285-291.

Wedel $\mathrm{N}$ et al. 1983 Ultrastructural effects of Clostridium difficile toxin B on smooth muscle cells and fibroblasts. Experimental Cell Research 148: 413-422.

Yolken R H et al. 1981 Enzyme immunoassay for the detection of Clostridium difficile antigen. Journal of Infectious Diseases 144: 378 . 